Digital Press Social Sciences and Humanities

Participative Based Social Entrepreneurship Training for Community Empowerment

Dayat Hidayat and Ari Putra

Proceeding of The Non-Formal Education International Conference 2020

Alim Harun Pamungkas, Jamaris, Solfema (eds) 


\title{
Participative Based Social Entrepreneurship Training for Community Empowerment
}

\author{
Dayat Hidayat ${ }^{*}$, Ari Putra ${ }^{2}$ \\ ${ }^{1}$ Community Education Department Faculty of Teachers Training and Education University of Singaperbangsa Karawang, Indonesia. \\ ${ }^{2}$ Community Education Department Faculty of Teachers Training and Education University of Ibnu Khaldun Bogor, Indonesia \\ *e-mail: dayat.hidayat@fkip.unsika.ac.id
}

\begin{abstract}
The purpose of the study is to describe the process of social entrepreneurship and empowerment as the ultimate goal of improving the economic welfare of the community. The research was conducted using a qualitative approach of case study method to analyze social entrepreneurship training based on community participation in accordance with real conditions in the field. The results of this study conclude that first, participatory social entrepreneurship training strategy shows the stronger the active participation of the community in developing the environmental potential in various aspects of development. Social entrepreneurship aims to create social value that is beneficial to society. The development of social entrepreneurship uses social principles and business ventures to create social change and build various types of businesses that are social. Training managers involve the active participation of communities in planning, implementing, and assessing their impact on the social and economic welfare of the community. The results of the training show the growing aspects of empowerment and community empowerment in solving the social and economic problems it faces. Second, the outcomes and impacts of training show an increase in self-reliance, self-confidence, and community self-reliance. The impact of the social entrepreneurship training process can improve the social and economic well-being of the community. Communities can participate in decision-making processes that concern themselves and their communities. Communities can collect natural and human resources within the scope of their communities and analyze situations and identify their development strategies to improve the social and economic welfare of the community.
\end{abstract}

\section{Keywords}

community empowerment, participatory based, social entrepreneurship training

\section{Introduction}

Community empowerment is a development concept that emphasizes improving the economic aspect without ignoring the social values that developed in its environment. Community empowerment is a concept of economic development that encapsulates social values. This concept reflects a new paradigm of development, which is "people-centered, participatory, empowering, and sustainable" (Chambers, 1985). Empowerment is a process of strengthening the community to participate in supervising and influencing various developmental events and institutions affecting their lives. Empowerment is the process of prioritizing the community to improve knowledge, attitudes and skills, so it can affect the lives of themselves and the community.

The concept of "empowerment" is a program that is often implemented by a particular group or group that has sensitivity and concern for the social condition of the community that has no potential. Empowerment is a community development process that seeks to increase self-awareness critically and together builds community institutions. Empowerment is an effort to be able to independently create a conducive climate of development to create the potential development and ability of the community itself. Community empowerment does not look at the structural hierarchy, because the government and society collectively respect each other's roles, duties and functions. With the empowerment of society is an effort to improve human dignity, especially at the level of society to escape from economic poverty conditions. 
In the implementation of community, empowerment requires a variety of strategies or specific indicators. The process of community empowerment needs to involve various parties to ensure the effectiveness and efficiency in applying innovations in order to realize the welfare of the community. In practice, it should place or position the community not as a target of empowerment but as the main actors who play an active role in developing all the potential that exists. Thus, motivation is needed by the community to be able to recognize their true identity and potential. Principally the main purpose of the empowerment process is to create an independent community situation and condition.

Today many community empowerment efforts are implemented, one of community empowerment is through entrepreneurship training. Community entrepreneurship training has a dimension of community empowerment. This training is a process of empowerment is not just a process of conveying curiosity and skills, but to prioritize efforts to raise and develop the ability of the economy. Increasing the ability of knowledge, skills, and entrepreneurial attitude, the training process is expected to overcome or solve the problems that society faced in life. This training is a community economic empowerment that prioritizes the critical ability of the community in analyzing every economic, social, and political situation it faces and develops its skills further in improving its standard of living. Thus, they are not dependent on the power of the people or other parties either economically, socially, or politically (Kindervatter, 1979, pp. 12-13).

The form of entrepreneurship training that is widely developed is social entrepreneurship. The development of social entrepreneurship has become increasingly popular in recent years (D Bornstein, 2006, p. 1). Dess, Jed, \& Peter (2001) and Nichols (2008) suggests that over time, social entrepreneurship has become a worldwide issue. This movement, then increasingly spread and expanded in various regions in various countries (Bornstein \& Davis, 2011; Elkington, 2006). Dhewanto (2013, p. 47) explains that social entrepreneurship works by defining certain social problems and then organizing, creating, and managing social enterprises to achieve the desired change. Furthermore, not only spread, but this movement has also been able to provide a positive impact for community members. Social entrepreneurship has impacted communities, such as improving access to health for the poor, promoting peace in conflict areas, helping farmers out of poverty and others. This movement is the antithesis of a socio-political based development program that tends to impose a topdown model on society (Skoll, 2009, p. 3).

In the implementation of social entrepreneurship development, community participation is a contributing factor to its success. The process of social entrepreneurship training involving the participation of the community in the process involves a person or a group of people when planning, implementing, and evaluating them. Hornby (2004) perceives participation to mean the act of taking part in an activity or event. It simply means taking an active part in an activity. Participation means involvement or commitment to an activity accompanied by orientations and beliefs, feelings and ideas (Courtney, 1992). Participation is the participation of a person in a social group to take part in the activities of his community, outside his own work or profession (Theodorson, 1969 in Theresia, Nugraha, \& Mardikanto, 2015, p. 196) .

Principles in involving direct community participation in various economic development programs can be achieved if the community consciously participates in, at the beginning of planning, the process and assessment of the results. Community involvement from the beginning to the end of the development program will guarantee a process of good empowerment. This condition will realize a well-trained community to carry out development. Without the preconditions, namely the development of political education, the participation of the community in implementing the development will not get many good results.

The development of social entrepreneurship training that involves community participation puts forward the notion of a society can build through a full, deliberate participation based on personal experience and abilities. This model illustrates broadly the principles of the adult learning model. This principle has the view that adults can learn best from, and through their own experience. Identified learning needs from adult experience can develop conceptual and practical understanding, to apply learning to the underlying needs. This cycle is generally said to be a learning cycle that is directly related to the experience of adults. In developing a community-based entrepreneurship training model, various methods help adults through the learning and cultivating cycle of learning.

A fundamental issue in the implementation of entrepreneurship-based training on community participation should involve the community directly in planning the development preconditions to be implemented. Community involvement in planning an entrepreneurship training program will clarify what the community actually wants and will do in developing its business. The process of direct involvement of community elements in developing entrepreneurship programs will provide the trust and legitimacy of the formulation of training programs. The more people who participate in identifying the 
formulation of entrepreneurship training goals the better the achievement of the outcomes. In principle, community involvement in the formulation of the objectives of entrepreneurship training will increase awareness, knowledge, attitudes, and skills of the community in formulating the goals of entrepreneurship training will increase awareness, knowledge, attitude, and skills of the community to develop their business.

\section{Methods}

This study is discussed by using a descriptive qualitative that related to social entrepreneurship training, social entrepreneurship training based on community participation, and community empowerment from various literary sources. The analysis is conducted to find conclusions that can be justified scientifically. This study used analytical research methods that investigate concepts through theoretical analysis. The researchers identified, studied, and then cataloged the data to gain an understanding of the concept of social entrepreneurship training, social entrepreneurship training based on community participation, and community empowerment that can be observed directly or indirectly. The theoretical concept is the main data. The researcher interprets the data and facts to get an explanation of the concepts of social entrepreneurship training, social entrepreneurship training based on community participation, and community empowerment of collecting societies precisely and clearly to draw conclusions. The technical data analysis used is an interactive model through the stages of data collection, data reduction, display data, and conclusion/verifying.

\section{Discussion}

\subsection{Social Entrepreneurship Training}

The basic principle of social entrepreneurship training involving community participation is carried out through the excavation of the full potential of society in its implementation. This training strategy shows stronger community participation to maximize the development of the environment in its various potentials. The community develops a strategy for managing social entrepreneurship training based on community needs. Various training institutions involve the active participation of the community in the planning, implementation, and assessment of social entrepreneurship training to support the improvement of social and economic welfare.

Kaswan \& Akhyadi (2014) argued that entrepreneurship development in Indonesia is still dominated by relatively low-educated entrepreneurs, of which $27 \%$ are entrepreneurs, $60 \%$ of whom are middleeducated, while PT graduates are $40 \%$. This condition does not match the employee position of most of the graduates of PT (40\%) while senior/vocational education, first, elementary and not finished school $27,16 \%, 9 \%$, and $6 \%$ respectively. This condition indicates that education in Indonesia has failed to create people with the personality and entrepreneurial nature, and more to build the nature and personality of the workers, and others.

Social entrepreneurship has evolved as a form of solving social problems in the real-life processes of society. As a new field of study, social entrepreneurship develops separately from other disciplines, and even its understanding is often confused with these disciplines. Although the definition of social entrepreneurship is not yet standard and its boundaries are unclear, the focus is on achieving economic efficiency and social innovation growing in a society that is trying to improve its present and future wellbeing. Social entrepreneurship and its methods, borrowed from the business world, are increasingly popular in helping to solve social problems and may also earn income from them. Social entrepreneurship today becomes one of the newest solutions to social problems, whether local, regional, national, or international.

Social entrepreneurship differs conceptually from business entrepreneurship. Where social entrepreneurship is more focused on the creation of capital than the social value built. While business entrepreneurship is more focused to open a new business or run an existing business with the aim of profits business owners. The managers of social entrepreneurship are closely related to non-profit organizations. But basically, it is a bit different where companies keep looking for profits for capital to make positive changes in society. Drucker (2006) defines entrepreneurship by focusing on opportunities 
that see entrepreneurs as economic actors who utilize and create opportunities in possible changes in society such as technology, consumer preferences, and social norms. An entrepreneur and entrepreneur always looking for a change, responds, and exploits it as an opportunity. Entrepreneurs have forwardthinking by looking at the possibilities of the problems. Thus social entrepreneurship is the process of recognizing and being able to capitalize on the opportunities of social problems to create social value.

Entrepreneurship is the first aspect of the concept of social entrepreneurship. Social entrepreneurship is conceptually unlikely to exist without the basic concept of entrepreneurship. (Zimmener \& Norman, 1996, p. 51) suggests that entrepreneurship is: applying creativity and innovation to solve the problem and to exploit that people face every day. The essence of the competence of an innovative and creative entrepreneur. Furthermore, Winarto $(2004$, p. 2) argued that entrepreneurship is a process of doing something new and different to create prosperity for the individual and provide added value to the community.

In its development, social entrepreneurship is one of the entrepreneurial processes. Many academics agree on the fact that social entrepreneurship identifies opportunities to encourage change in society to solve new social problems, by providing new ideas and providing new types of services and by seeking new or more efficient integration of resources. Durieux and Stebbins (2010) argue that social entrepreneurship is usually associated with social innovation. In addition, social entrepreneurship can be reviewed from three main elements: motivation, organization, and society.

Nichols (2006) suggests social entrepreneurship is a blend of nonprofit management and commercial entrepreneurship, driven by the paradigm and innovation of business, charitable activities, and social movements. While Borzaga, Depedri, \& Tortia (2010) argues that social entrepreneurship is a model for half-public goods introduced by nonprofit organizations for the purpose of decentralization and social welfare systems.

Developing a strategy of social entrepreneurship concepts many institutes or community organizations that move the social field. Social entrepreneurship can be regarded as an institution that innovates in the social field by doing business with the main purpose of the social welfare community. The principle of social entrepreneurship is not seeking profit through income, but rather prioritizing the completion of the social welfare needs of the community. Social entrepreneurship, the simultaneous pursuit of economic, social, and environmental goals by companies in order to find the cause of problems in society and the environment (Haugh, 2007). Richez \& Petrella (2013) suggests that social entrepreneurship is a different type of entrepreneurship and aims to create social value, which is a benefit to large scope for society.

In developing a social entrepreneurship strategy, managers use the principles of business, business, and even capitalism itself to bring about social change through the establishment and development of various types of businesses, some of which are social. Managers set up small, medium, or large nonprofit businesses designed to improve social problems in the community. Kaswan \& Akhyadi (2014) argues that social entrepreneurship is usually used to describe all economic programs that serve social missions and/or environmental missions as well as reinvest most of its surplus in support of its mission. Although this definition is not yet standard and the boundaries are unclear, the focus is on achieving economic efficiency and social innovation, which occurs in the context of major uncertainty in the future.

The extent of the scope of social entrepreneurship encourages the birth of many studies that try to illustrate more clearly the character of social entrepreneurship as in the following table:

Table 1 Social Entrepreneurship Context

\begin{tabular}{lll}
\hline $\begin{array}{l}\text { Characteristics that } \\
\text { explain }\end{array}$ & \multicolumn{1}{c}{ Example } & \multicolumn{1}{c}{ The Contextual Issue } \\
\hline Context of the Social & $\begin{array}{l}\text { Effort Public welfare, matters related to } \\
\text { saving the environment, development, } \\
\text { and donation / social assistance }\end{array}$ & $\begin{array}{l}\text { Acting as a privatization agent of public } \\
\text { goods, not bringing political issues, the } \\
\text { narrow focus can encourage dependency }\end{array}$ \\
$\begin{array}{l}\text { The process of social } \\
\text { enterprise }\end{array}$ & $\begin{array}{l}\text { A strong bond with stake-holders; hire } \\
\text { and train disenfranchised; act as a } \\
\text { mediator/trade bridge }\end{array}$ & $\begin{array}{l}\text { Stakeholder selection criteria/separate from } \\
\text { the process; empowerment of stakeholders }\end{array}$ \\
$\begin{array}{l}\text { Achievements and } \\
\text { implications }\end{array}$ & $\begin{array}{l}\text { Improving public welfare; more powerful } \\
\text { individuals; crisis reduction }\end{array}$ & $\begin{array}{l}\text { Perhaps the social impact is not measurable, } \\
\text { and the program is often short-term }\end{array}$ \\
\hline
\end{tabular}

Source: Nichols (2008, p. 14) 
Further, Short, Moss and Lumpkin (2009) as quoted by Wankel and Pate (2014, p. 17), social entrepreneurship is described as follows: First, we view social entrepreneurship as a process of creating value by combining resources in new ways. Second, these resources combinations are meant primarily to explore and exploit opportunities to create social value by stimulating social change or meeting social needs. And third, when viewed as a process, social entrepreneurship involves the offering of services and products but can also refer to the creation of new organizations. Social entrepreneurship has some dimensions. Among the most important are: first, the process of value creation, second, integration of resources, third, exploring and exploiting opportunities, fourth, social change/social fulfillment, and fifth, offering services and products, or creating new organizations.

\subsection{Social Entrepreneurship Training Based on Community Participation}

In relation to community entrepreneurship training, Riyanto (2000, pp. 5-6) suggests that entrepreneurship training is a kind of education that teaches to create their own business activities. Such training is carried out by a) building up the faith, soul, and spirit, b) developing and developing the mental attitude and entrepreneurial character, c) developing thinking power and ways of entrepreneurship, d) advancing and developing self-mobilizing power, e) understanding and mastering techniques for dealing with risks, competition and a process of cooperation, f) understanding and mastering the ability to sell ideas, g) having management or processing abilities, and h) possessing certain skills including the acquisition of a particular foreign language for communication purposes.

Nadler (1982) in Sudjana (2007) suggests that the training objectives are essentially a statement outlining a proposed change that will occur to the trainee, ie changes after the trainee completes his learning experience in the training. A more complete objective of training can be given as a formula for the outcomes of output (output) and the outcomes to be achieved by the training. Next Robbins (2001, p. 282) suggests training meant formal training that is planned in advance and has a structured format.

The concept of social entrepreneurship training involving community participation has a philosophical, psychological, and sociological foundation that sees the need for a change in the framework of the training process that can foster the empowerment and empowerment aspects of the community in solving the economic needs problems it faces. The development of this training model is based on adult education, adult education, human brain research, the Lazanov model, innovation of modern approaches such as accelerated learning and quantum learning (Sumpeno, 2009, p. 46). An important indicator of achieving the goal of entrepreneurship training is the growth of business and social life in the individual of each learner so that it can form a community of "business entrepreneurs" whose impacts have implications on improving the quality of economic activities of the community to reduce poverty and tackle the increasingly increasing unemployment problem.

Social entrepreneurship training is actually aimed at two targets, namely participation, and organization. With the training of social entrepreneurship, it is expected to improve the behavior of society and the improvement of the organization itself that is to be more effective. In the context of social entrepreneurship training that involves community participation is the effort of trainers to include trainees in program planning, program implementation, and program evaluation of learning activities (Sudjana, 2004, p. 129). Community participation in development activities, as an activity, Verhangen (1979) in Theresia et al., (2015, p. 197) states that participation is a special form of interaction and communication with respect to the division of authority, responsibility, and benefits. The growth of such interaction and communication is based on the awareness of the concerned concerning: first, unsatisfactory condition, and must be improved; second, the condition can be improved through human activities or community itself; third, the ability to participate in activities that can be done, and fourth, the existence of confidence, that he can make a useful contribution to the activities concerned.

Defourny and Kim (2011) suggest social entrepreneurship is a dynamic model of participation between government structures, cooperation, and common ownership. Furthermore, the analysis of social capital on the importance of community participation in development, according to Wolcook and Narayan, (2000) in Theresia et al., (2015, p. 197) suggest that participation is needed to develop synergies in the relationship between government and society as well as synergy in community networks. Participation is an important component in generating self-reliance and empowerment processes (Craig and May 1995, in Hikmat, 2014). Hikmat (2014) further explains that empowerment and participation are potential strategies in order to improve economic, social, and cultural transformation. This process will eventually create a people-centered development.

In the process of community development, participation is a manifestation of awareness, awareness, and responsibility of the community that views the importance of development in an effort to improve 
the quality of life and their lives. That is, participation with various types of community provided, it is realized not only the obligations that must be implemented by government officials themselves but also require awareness and responsibility of society that will be improved and improved the quality of life.

\subsection{Community empowerment}

The main goal of social entrepreneurship training based on community participation is to empower community welfare sustainably. The essence of the empowerment process, Ife (1995) argues that the revitalization of group roles can only be done through participatory processes, from the stage of formation or initiation, planning, action, monitoring or evaluation, to the sharing of results obtained by the group. Furthermore, Chamala (1995) with its concept of Participative Action Management (PAM) underlines that an effective group is formed within a minimum of six months, from initiation to the group development stage. In the initiation stage, for example, a joint awareness of the existence of problems and needs.

Empowerment is a process of self-reliance self-help to strengthen the bargaining position of lowerlevel society against the suppressive forces in all areas and sectors of life (Sutoro, 2002). The goal of community empowerment is not only to fulfill basic needs or provide mechanisms to prevent the occurrence of sustainable poverty (safety net). But as an attempt to find alternatives to the concepts of social and economic growth of society in the past. This concept evolved from the efforts of many experts and practitioners to find what among others by Friedman (1992) referred to as alternative development, which desires 'inclusive democracy, economic growth equality, gender equality and inter-generational equaty' (Kartasasmita, 1996).

Through participatory-based entrepreneurship training, the community is expected to first, determine the outlook on the future of the community to be realized; secondly, identify and assess the potential of their own socio-economic environment; third, play a role in planning the development of social entrepreneurship, fourth, human resources and natural potentials that can be utilized around the scope of its community; and fifth, gain experience in stating, analyzing situations and identifying appropriate, proper and realistic social entrepreneurship training strategies so as to improve the welfare of the community.

Community empowerment is not merely to provide individual empowerment, but also social institutions. Community empowerment in its implementation, inculcate modern cultural values, such as work motivation, live hard work, thrift, welfare, and responsibility in the role of each member of society. In addition, various social institutions are reformed and integrated into development activities and position the various roles of the community in them. Increasing public participation in the decisionmaking process that concerns the lives of self and society is very important to note. Thus, community empowerment is closely related to the introduction, stabilization, culture, and practice of democratic life.

The process of participation encourages people to exercise the right to decision-making directly or indirectly concerning the interests of the people. Community participation can be realized in line with the growth and development of public confidence in the government. This believer's trust will grow if every member of society gets the opportunity to obtain equal service in developing social entrepreneurship in society. Positioning the role and function of the community as the main actors in the development of social entrepreneurship required various alternative strategies of community empowerment. One of the strategies that is appropriately used is the social entrepreneurship training program to the community. This social entrepreneurship training program is expected to increase self-reliance and self-reliance so as to achieve social welfare in the community.

\section{Conclusions}

Participatory social entrepreneurship training strategy shows the stronger role and function of society in growing and developing various potencies in its environment to carry out social development of society. Social entrepreneurship is an effort undertaken to cultivate and develop the social values prevailing in the community to feel the benefits in life. The development of social entrepreneurship uses business and social principles to bring about social change by establishing and building various types of businesses, some of which are social.

In its implementation, social entrepreneurship training managers set up small, medium, or large nonprofit businesses designed to solve and improve social issues. Various training institutions involve the 
active participation of the community in planning, the implementation process including its assessment to improve community welfare. Participatory social entrepreneurship training has a basic view of the need to change the paradigm of training programs that can grow and develop various aspects of empowerment and community empowerment so as to overcome and solve the social and economic problems it faces.

The impact of participatory social entrepreneurship training is aimed at realizing community empowerment. Community empowerment is a process of independence, strengthen, and improve the social and economic status of the underclass. Community empowerment is a means to consolidate, cultivate, and practice democratic life. Social entrepreneurship training is a decision-making process involving community participation in determining materials, methods, and results in an assessment that impacts on community empowerment.

\section{References}

Bornstein, D. (2006). Changing the World: Social Entrepreneurship and the Power of New Ideas. Insist PressWorld Conscience.

Bornstein, David, \& Davis, S. (2011). Social Entrepreneurship: What Everyone Needs to Know Teaching Notes. Retrieved from http://ashokau.org/wp-content/uploads/2010/12/Social-Entrepreneurship-What-EveryoneNeeds-to-Know-Teaching-notes-final.pdf

Borzaga, C., Depedri, S., \& Tortia, E. (2010). The Growth of Organizational Variety in Market Economies: The case of Social Enterprises (No. N.003.10).

Chamala, R. S. (1995). Overview of Participative Action Approaches in Australian Land and Water Management. In S. Chamala \& K. Keith (Eds.), Participative Approaches for Landcare: Perspective, Policies, Program. Brisbane, Australia: Academic Press.

Chambers, R. (1985). Rural development: putting the last first. London; NewYork: Longman.

Courtney, S. (1992). Why Adults Learn: Towards a Theory of Participation in Adult Education. London: Routlege.

Defourny J. dan Kim, S. (2011). Emerging Models of Social Enterprise in Eastern Asia: a Cross-Country Analysis. Social Enterprise Journal, 7(1), 86-111.

Dess, J. G., Jed, E., \& Peter, E. (2001). Enterprising Non Profit: A tool for Social Entrepreneur. Wiley Non Profit Series.

Dhewanto, W. (2013). Intrapreneurship Kewirausahaan Korporasi. Bandung: Penerbit Rekayasa Sains.

Drucker, P. F. (2006). Innovation and Entrepreneurship: Practice and Principles. Australia: Perfect bound.

Durieux, M. B., \& Stebbins.R.A. (2010). Social Entrepreneurship for Dummies. Canada: Wiley Publishing, Inc.

Elkington, J. (2006). Governance for sustainability [Electronic Version]. Retrieved from The Author website: http:/www.africagrowth.net/reportingaccountability/images/stories/library/reportingandaccountability/go vernanceforsustainability.pdf

Friedman, J. (1992). Empowerment the Politics of Alternative Development. Cambridge, USA: Blackwell Publishers.

Haugh, H. (2007). New Strategies for a Sustainable Society: The Growing Contribution of Social Entrepreneurship. Business Ethics Quarterly, 17(4), 743-749.

Hikmat, H. (2014). Strategi Pemberdayaan Masyarakat. Bandung: Humoniora. 
Hornby, A. S. (2004). Oxford Advanced Learners Dictionary. Oxford: University Press.

Ife, J. W. (1995). Community Development: Creating Community Alternatives-vision, Analysis and Practice. Melbourne: Longman.

Kartasasmita, G. (1996). Pembangunan Untuk Rakyat - Memadukan Pertumbuhan dan Pemerataan. Jakarta: PT. Pustaka CIDESINDO.

Kaswan, \& Akhyadi, A. . (2014). Social Entrepreneurship: Mengubah Masalah Sosial Menjadi Peluang Usaha. Bandung: Alfabeta.

Kindervatter, S. (1979). Nonformal Education as An Empoworing Process. Massachusetts: Center for International Education University of Massachusetts.

Nichols, A. (2006). The New Social Entrepreneurship. What Awaits Social Entrepreneurial Ventures? Equal Opportunities International, 26(7), 729-732.

Nichols, A. (2008). Social Entrepreneurship: New Models of Sustainable Social Change. Oxford.

Richez, B. N., \& Petrella, F. (2013). Social Entrepreneurship. In L. G. Carayannis (Ed.), Encyclopedia of Creativity, Invention, Innovation and Entrepreneurship. Springer Science + Business Media, Springer.

Riyanto, A. (2000). Kapita Selekta Kewirausahaan. Bandung: Yapemdo.

Robbins, S. P. (2001). Training in Interpersonal Skills (5th Edition). Selangor, SG, Malaysia: Prentice Hall.

Skoll, J. (2009). Social Entrepreneurship: Power to Change, Power to Inspire. Retrieved from http://wwwtc.pbs.org/now/shows $/ 537 /$ Shifting-Power-Dynamics

Sudjana, D. (2004). Manajemen Program Pendidikan, untuk Pendidikan Nonformal, dan Pengembangan Sumber Daya Manusia. Bandung: Falah Production.

Sudjana, D. (2007). Sistem dan Manajemen Pelatihan, Teori dan Aplikasi. Bandung: Falah Production.

Sumpeno, W. (2009). Sekolah Masyarakat, Penerapan Rapid-Training Design Dalam Pelatihan Berbasis Masyarakat. Yogyakarya: Pustaka Pelajar.

Sutoro, E. (2002). Pemberdayaan Masyarakat Desa. In Materi Diklat Pemberdayaan Masyarakat Desa, Badan Diklat Provinsi Kaltim, Samarinda, Desember.

Theresia, K. A., Nugraha, P. G., \& Mardikanto, T. (2015). Pembangunan Berbasis Masyarakat. Bandung: Alfabeta.

Wankel, C., \& Pate, L. (2014). Emerging Researh Direction in Social Entrepreneurship. Springer Science + Business Media, Springer.

Winarto, P. (2004). First Step to be An Entrepreneur. Jakarta: Alex Media Komputindo.

Zimmener, W. T., \& Norman, M. S. (1996). Entrepreneurship and the New Venture Formation. New Jersey: Prentice Hall International Inc. 